\title{
>Existential isolation in Whisky (2004), reading uruguayan cinema beyond the concept of small cinema
}

\author{
>Isolamento existencial em Whisky (2004), lendo cinema uruguaio \\ para além do conceito de small cinema
}

por Cesar Lopes Gemelli

Department of Spanish and Portuguese, Studies of the Portuguese-speaking World, Ohio State University. E-mail: lopesgemelli.1@osu.edu. ORCID: 0000-0003-1245-060X.

\begin{abstract}
The Cinematography in Whisky (2004) is essential in the directors' efforts to explore existential isolation. The incompleteness of knowledge, the uncrossable gaps between people, and the impossibility of communion among individuals are some of the themes explored in this film, directed by Juan Pablo Rebella and Pablo Stoll. These are mostly absent in the scholarship about the movie, which tends to focus on the concept of small cinema. The present text aims to build on these discussions to propose a reading of Whisky as a work of art that, although made within a very specific context of production, is not limited by it.
\end{abstract}

Keywords: Cinematography. Uruguayan cinema. Small cinema.

\section{Resumo}

A direção de fotografia e o enquadramento em Whisky (2004) são essenciais na exploração do isolamento existencial. A incompletude do conhecimento, os espaços intransponíveis entre pessoas e a impossibilidade de comunhão entre indivíduos são alguns dos temas explorados por esse filme dirigido por Juan Pablo Rebella e Pablo Stoll. Esses temas estão quase ausentes na literatura sobre o filme, que tende a focar no conceito de small cinema. O presente texto tem por objetivo acrescentar aos debates mencionados propondo uma leitura de Whisky como uma obra de arte que, embora feita em um contexto de produção bastante específico, não é por ele limitado.

Palavras-chave: Cinematografia. Cinema Uruguaio. Small cinema. 
Whisky (2004) is a film directed by Juan Pablo Rebella and Pablo Stoll that is part of the New Uruguayan Cinema ${ }^{1}$ movement and received prizes in Cannes, Thessaloniki, and Huelva. Most of the scholarly discussions regarding New Uruguayan Cinema, including, Whisky, seem to focus on their production context (small cinema) and their relation to big or commercial cinema on a larger scale (usually referred to as just cinema without any adjectives). This paper proposes the validity of a reading of Whisky beyond its contexts of production and reception. Whisky can be understood as a movie in which both the formal composition and the mise-en-scène are pivotal in conveying its meanings: the existential isolation of humanity and the uncrossable gaps between people. The partial erasure of Uruguayan elements in the mise-enscène as well as the cinematography are integral factors to this analysis. The highly sophisticated arrangement of the camera's framing emphasizes the limits of human perception, the isolation of existence, and the chasms that bar any kind of communion. Performances of identity cannot be completely understood by anyone and it suggests that fragmented identities receive even more disjointed perceptions. The meta-cinematic allusions in the movie advance a dual reading of Whisky: a local and a global one. If, on the one hand, the film intends to appeal to international audiences, on the other, it seeks to foster discussion of Uruguayan identities in which its form is an integral part of its meaning.

Whisky's director of photography is Bárbara Álvarez. The script was written by the directors and Gonzalo Delgado. Production and editing were carried out by Fernando Epstein. Its first exhibition was at the Cannes Film Festival, where it won the Prix du Regard Original. In the movie, Jacobo Köller (Andrés Pazos) is the owner of a decadent sock factory, which he runs with the

\footnotetext{
${ }^{1} \mathrm{New}$ Uruguayan Cinema refers to the increase in film production that occurred in Uruguay after the turn of the century. It has its roots in the end of the military dictatorship in the mid1980s. For a more detailed discussion, Cf. Martin-Jones, David, and María Soledad Montañez. Uruguay Disappears: Small Cinemas, Control Z Films, and the Aesthetics and Politics of AutoErasure." Cinema Journal, vol. 53, no. 1, 2013, pp. 26-51. "Cinema in Progress: New Uruguayan Cinema." Screen, vol. 50, no. 3, Oct. 2009, pp. 334-44. by the same authors.
} 
help of Marta Acuña (Mirella Pascual). One year after the death of Jacobo's mother, his brother, Herman Köller (Jorge Bolani), comes back to Montevideo to set their mother's gravestone. Herman lives in Brazil with his family, where he also runs a sock factory that seems to be more modern and successful than his brother's. Jacobo asks Marta to stay at his place during his brother's visit. Even though he does not actually say the words, he is asking Marta to pose as his wife. After the gravestone ceremony, the three of them go to Piriápolis, where the brothers used to spend their vacation as kids. The city is mostly empty, suggesting that it is no longer an attractive tourist destination. The film seems to suggest that Marta sleeps with Herman during the days they spent at the hotel. On their last night there, Jacobo goes to a casino and gambles the money that his brother gave him to help cover the expenses of their mother's last years and funeral. He bets everything on black 24 and wins. He keeps a small share for himself and gift wraps most of it and gives it to Marta, who does not show up for work the next day.

Whisky deals with themes of existential isolation within a set of aesthetic choices. These choices are framed by a discussion that necessarily deals with the notion of national cinema. The concept of national cinema is explicitly or implicitly present in most, if not all, scholarly discussions about small cinema, including those of Hjort, Fuica, David Martin-Jones and María Soledad Montañez, and William Brown. However, this concept needs to be reframed. Even though the main argument of this paper is a defense of a reading of Whisky beyond those that limit it to its contexts of production and reception; Uruguay, as a nation or as an imagined community, is at least implicitly present in several concepts addressed in the scholarly debates about the movie. National cinema is a debated topic for the abovementioned authors in different ways, but tends to focus on the movie's production context and not on its reading per se. When it does, national seems to become mediated by Anderson's understanding of imagined communities, meaning that it refers to the cultural aspects of this social construct in a way that conveys information about 
practices and meanings within that community. This theme comes back again in Fuica's discussion of local and global as a debate mediated by the film's attempt to appeal to audiences beyond Uruguay itself. The concept of national cinema is present in David Martin-Jones and María Soledad Montañez's discussion of the funding available to Uruguayan producers. It also underlies Fuica's discussion of the presence of Uruguayan cinema in international festivals whose organization and selection of movies tend to rely heavily on the idea of nationality. Brown presents a somewhat more metaphysical argument about non-cinema that is, however, still dependent on the notion of national cinema.

Mette Hjort, on the other hand, opens her book with a citation by Dudley Andrew that outlines a very pragmatic approach to the matter at hand, and proceeds to present a moderate acceptance of the "new critical vocabulary - 'world cinema', 'transnational cinema', 'regional cinema'"'2 emerging in film studies recently. The definition of small nation cinema is presented in relation to a "single dominant other, Hollywood". As such, national cinema seems to require a reevaluation of its usefulness as a category, since it is a response to an academic and institutional awareness of the colonialist aspect of neo-liberal globalization. Andrew Higson's work on the matter (both The Concept of National Cinema ${ }^{4}$ and the later revisiting of the same topic The Limiting Imagination of National Cinema ${ }^{5}$ ), as well as that of many other scholars, points out how nation-states "at least since the mid 1910s" intervene directly in the film industry. For example, recent Freedom of Information Act requests in the United States keep producing abundant evidence of the close relationship between Hollywood and the State ${ }^{7}$. As such, the notion of national cinema

\footnotetext{
${ }^{2}$ Mette Hjort, Cinema of Small Nations, 2007, p. 1.

${ }^{3}$ Ibidem, p. 2.

${ }^{4}$ Andrew Higson, The Concept of National Cinema (1989), 2002, p. 61.

${ }^{5}$ Idem, The Limiting Imagination of National Cinema, 2000, p. 63.

${ }^{6}$ Idem, The Concept of National Cinema (1989), 2002, p. 61.

${ }^{7}$ For a short compilation of these, cf. Washington DC's role behind the scenes in Hollywood goes deeper than you think (Alford, "Washington DC's Role behind the Scenes in Hollywood Goes Deeper than You Think") and Toby Miller et al. A more detailed account is available on Reel
} 
emerges both as a target of imperialist propaganda and practices and, at the same time, as a space of resistance and insurgence. In this context, it is important to contextualize David Martin-Jones and María Soledad Montañez's comment on the struggle of Uruguayan cinema, the so-called erasure of Uruguayan geographical spaces mentioned by Fuica, and Brown's argument of non-cinema within Hjort's Jamesonian argument of globalization that reveals how this tension informs both content and form ${ }^{8}$.

Whisky inhabits the space between these conflicting forces and negotiates its representation of Uruguayan identities to propose a Uruguayan understanding of social relationships and selfhood that transcends its own geographic and social limitations. The uncrossable gap between an individual's social performance and its perception by the other, as well as the incompleteness of human understanding, are proposed as universal within human experience because this could only be understood as such in the erasure of Uruguay. If that were not the case, analytical interpretations of Whisky would engage with matters of alterity that come close to exoticizing the other beyond understanding'. In other words, Whisky, in its form and meaning, negotiates its message in a context of small-nation cinema that demands some erasure of local aspects of Uruguayan experience in favor of a promise of profitability that would (and did) enable the people involved in its production to carry on their work, convey their message, and mark the presence of Uruguayan elements on screen.

Brown's proposition of Uruguayan cinema as non-cinema, i.e., a cinema beyond the current notion of commercial cinema heavily attached to capitalism and profits, engages with the concept of national cinema as a target of imperialist practices. The author articulates his argument taking as a base

power: Hollywood cinema and American supremacy (2010) and The Political Impact of the Department of Defense on Hollywood Cinema (2016).

${ }^{8}$ Mette Hjort, Op. Cit., 2007, p. 17.

'Zhang Longxi's "The Tao and the Logos" presents an insightful description of this barrier of understanding due to limitations of the analytical self in face of an alterity taken as exotic. 
the idea of erasure as central to Uruguayan cinema. After a brief explanation about funding available for Uruguayan film-makers, Brown explains his view of the argument of David Martin-Jones and María Soledad Montañez.

For this reason, Uruguayan cinema struggles to exist, with David Martin-Jones and María Soledad Montañez pointing out how certain types of Uruguayan cinema by necessity erase the local, namely Uruguay itself, in order to create a transnational appeal that befits the transnational system of funding, and which might enable the films to reach a larger, international audience, thereby recouping the costs of making cinema/increasing the chances of making a profit. (...) In all cases, then, Uruguay is erased, suggesting that Uruguay and cinema are not compatible, or that Uruguay is non-cinematic. ${ }^{10}$

The incompatibility between Uruguay and cinema suggested above seems distant from Whisky's context. David Martin-Jones and María Soledad Montañez themselves argue that the movie has two reading keys: one for foreigners who are unfamiliar with the Uruguayan context and another for those who are acquainted with the Uruguayan context, which is a crucial step in their argument. Uruguay itself is not erased. It still permeates the whole movie and serves as a key factor in the discussion about identity (both Uruguayan as well as individual) in the movie. Uruguay and cinema are indeed very much compatible, and it is precisely the nuanced and subtle representation of Uruguayan culture and identity that maximize Whisky's message, relevance, and "transnational appeal"1. The abovementioned transnational appeal is the step that Brown needs so that he can characterize non-cinema as one that

does not suffer from the economic imperative of cinema and thus can risk failure with much greater ease. In this way, perhaps no single film that could be defined as non-cinema could 'overthrow' cinema. Rather, we can understand non-cinema more clearly as being defined by the small (..... ${ }^{12}$

Brown's claim of Uruguayan cinema as small or non-cinema on the basis of its ability to take risks precisely for its existence beyond commercial cinema seems to overlook Brown's own argument about the funding structure that he

\footnotetext{
${ }^{10}$ William Brown, Non-Cinema Global Digital Film-Making and the Multitude, 2018, p. 186.

${ }^{11}$ Ibidem, p. 186.

${ }^{12}$ Ibidem, p. 207.
} 
presents at the opening of the chapter. The limited funding available for small cinema creates economic pressure on the production companies on the supply side of the "supply and demand" model. Since funding is very limited both in its financial aspects as well as in the frequency it is awarded, the risk of producing movies in this context is great for anyone trying to make a living from filmmaking. In the case of Uruguay and Whisky, the professionals working for the company Control $\mathrm{Z}$ rely on this infrequent and small funding system to survive. Fernando Epstein, for example, works in editing as well as the postproduction of other movies in order to keep film-making as his profession ${ }^{13}$. Because of an "economic imperative" ${ }^{14}$ on the producing side Whisky, and other Uruguayan movies, and small cinema, in general, negotiate their forms and contents within the erasure of the local ${ }^{15}$. On the one hand, there are limited funding schemes and the "transnational appeal"16 to a wider audience, i.e., two economic imperatives, whereas on the other, there is the erasure of some Uruguayan elements on screen within a movie that makes deliberate use of framing to highlight that some components are indeed absent. The play between what is visible on-screen and what is off-screen is essential to Whisky as will be shown below.

Fuica explores this duality in terms of the global and local without leaving aside the content conveyed by the filmmakers. She focuses on aesthetic choices that echo the indie movies of the United States as a way to maintain transnational appeal. ${ }^{17}$

Since 2001 the time gap between successful films in international festivals has been much shorter and these young directors were to gain further international recognition with Whisky. The fact that the presence of Uruguayan films has become more frequent in these festivals reflects precisely the constant and increasing negotiation between the global and the local. In the case of 25 Watts this tension was present in both the aesthetic choices and post-production decision

\footnotetext{
${ }^{13}$ Miguel Ángel Dobrich, Duelo con el montajista y productor cinematográfico Fernando Epstein, 2018.

${ }^{14}$ William Brown, Op. Cit., 2018, p. 207.

${ }^{15}$ Ibidem, p. 186.

${ }^{16}$ Ibidem, p. 186.

${ }^{17}$ Ibidem, p. 186.
} 
regarding its materiality, which reflect the willingness to produce locally - among friends, telling their own stories - while benefiting from both national and international funding sources and exhibition outlets. ${ }^{18}$

Fuica's most valuable contribution to this debate is her mention of the filmmakers' desire to tell "their own stories"19 as shown above. This is the imperative that makes Whisky so compelling. Whisky and other Uruguayan films, as well as the filmmakers that are part of Control Z-the production company founded by the makers of 25 Watts and that now produces "most of the Uruguayan films which gained international recognition during this decade" ${ }^{20}$-have become an access point to Uruguayan and Latin American cinema. In Whisky, the story being told is one of identity, isolation, communion, and the impossibility of knowing someone beyond the self. To do so, the global and local need to be negotiated within the margins of imperialist cinema yet with careful consideration of "transnational appeal" ${ }^{21}$. Fuica also draws on Martin-Jones and Soledad Montañez for the identification of similarities "between American indies and the Uruguayan film Gigante" forth the argument that Uruguay is a cinematic nowhere in which any Spanish-speaking plot could happen. Fuica shows how the local and the global are negotiated within these movies, how the financial pressures and the appeal to international audiences end up interfering with and informing the aesthetic choices of the filmmakers so they can tell the stories they want to tell. In order words, the "transnational appeal" ${ }^{23}$ and the matter of the global and the local come together to form an aesthetic in Whisky upon which the individual isolation of subjects, their fragmented identities, and the impossibility of knowing someone can be discussed.

\footnotetext{
${ }^{18}$ Beatriz Tadeo Fuica, Uruguayan Cinema, 1960-2010: Text, Materiality. Archive, 2017, p. 131, emphasis ours.

${ }^{19}$ Ibidem, p. 131.

${ }^{20}$ Ibidem, p. 115.

${ }^{21}$ William Brown, Op. Cit., 2018, p. 186.

${ }^{22}$ Beatriz Tadeo Fuica, Op. Cit., 2017, p. 126.

${ }^{23}$ William Brown, Op. Cit., 2018, p. 186.
} 
Fuica ${ }^{24}$ goes on to argue that the erasure of Uruguayan themes in 25 Watts negotiates its meaning through American indie movies. In Whisky, an analogous argument can be made, not through indie movies, but through the usage of framing by the director of photography in relationship to "transnational appeal"25 in order to convey the filmmakers' "own stories"26. The relationship between erasure, negotiation, circulation, and the filmmakers' own stories are important in Fuica's argument.

\begin{abstract}
While these scholars' analysis could be probably extended to 25 Watts, I would suggest a different reading. Rather than considering that Stoll and Rebella's filmBest wishes 'erases' national identifiers, I argue that, by resorting to indie aesthetics, 25 Watts reflects tensions and negotiations. By reproducing certain aesthetics and ways of production, 25 Watts manages to both enter into dialogue with the outside, with the wider circulation of Indie films - when issues concerning the internationalisation of the country were sensitively discussed - and create a marginal space within the audiovisual products consumed nationally. ${ }^{27}$
\end{abstract}

In this case, the focus is on 25 Watts and not on Whisky. Yet Fuica's argument about tensions and negotiations are similarly valid. The alleged erasure of Uruguay allows it to go beyond small cinema through its "transnational appeal" ${ }^{28}$, which itself becomes a constituent of the film's form. Through the framing that constantly leaves important elements off-screen, Whisky emphasizes the incompleteness of our perception and of the characters themselves through its many meta-cinematic allusions as well as diegetically explicit miscommunications between the characters. The impossibility of communion between humans, the filmmakers' "own stor[y]"29, is told with and within a film form that embodies the financial struggles the makers went through and the need to appeal to international audiences.

David Martin-Jones and María Soledad Montañez's contribution is paramount to the understanding of Whisky as a movie that negotiates the

\footnotetext{
${ }^{24}$ Beatriz Tadeo Fuica, Op. Cit., 2017.

${ }^{25}$ William Brown, Op. Cit., 2018, p. 186.

${ }^{26}$ Beatriz Tadeo Fuica, Op. Cit., 2017, p. 131.

${ }^{27}$ Ibidem, p. 126.

${ }^{28}$ William Brown, Op. Cit., 2018, p. 186.

${ }^{29}$ Beatriz Tadeo Fuica, Op. Cit., 2017, p. 131.
} 
filmmakers "own stories"30 within the context of small cinema. The erasure of Uruguayan themes is not absolute, because

(...) Whisky presents international audiences with a low-budget indie or art film, with a character-driven plot, sparse action, minimalist comic acting and tightly controlled cinematography. However, for Uruguayan audiences Whisky is immediately recognizable as a film about Uruguay. Although the film's main focus is on two Jewish brothers, it also meditates on Uruguayan identity in a way that may not be immediately apparent to an outsider. ${ }^{31}$

The aforementioned authors claim that two readings of Whisky may be possible due to the coded mediation of Uruguayan identity. They detect both the "transnational appeal" ${ }^{32}$, as well as the local one (Fuica). Among the scholarly works discussed above, David Martin-Jones and María Soledad Montañez, followed closely by Fuica, seem to be closer to an argument that advances the reading of Whisky beyond one that restricts it to a reading of a Uruguayan film competing for an international audience against films with larger budgets from other places. There is also another possible perspective of interpretation of Whisky that, while relying on the negotiation of the global and local (Fuica) in the search for a transnational appeal (Brown), takes into consideration a sophisticated discussion of Uruguayan identity (Martin-Jones and Montañez), transcends its contexts of production and reception ${ }^{33}$, focusing mostly on the formal aspects of the film in order to advance an argument about isolation and the human condition.

Whisky is a Uruguayan movie that deals with isolation, the uncrossable gap between an individual's social performance and its perception by the other, and the incompleteness of human understanding. This incompleteness is suggested by the narrative economy of the movie and perhaps more importantly by the camera work of Bárbara Álvarez, which often uses the

\footnotetext{
${ }^{30}$ Ibidem, p. 131.

${ }^{31}$ David Martin-Jones and María Soledad Montañez, Uruguay Disappears: Small Cinemas, Control Z Films, and the Aesthetics and Politics of Auto-Erasure, 2013, p. 340.

${ }^{32}$ William Brown, Op. Cit., 2018, p. 186.

${ }^{33}$ In the same way that it is possible and common to read Shakespeare's Hamlet without limiting it to the social context of Elizabethan theater.
} 
border of the frame to stress that important events or objects influencing the narrative are beyond our view. Exploring the limits of social appearances and of our perception, the movie uses the pronunciation of the word whisky during picture taking. It does so in order to simulate smiles as a recurrent performance of fictional happiness that constitutes a frail facade of success and completeness that is ready to be torn down at the slightest examination.

The scene in which Jacobo and Marta take a picture together to improve the fiction they are presenting to Herman is key in binding form, content, and the main themes of the movie. In this static shot beginning at (0:29:33), Marta and Jacobo are taking a picture together at Marta's suggestion. Their diegetic goal is to frame the picture and set it in Jacobo's living room to create more veracity to the lie they are telling Herman. It is supposed to be a picture of their wedding, which never really happened (Image 1).

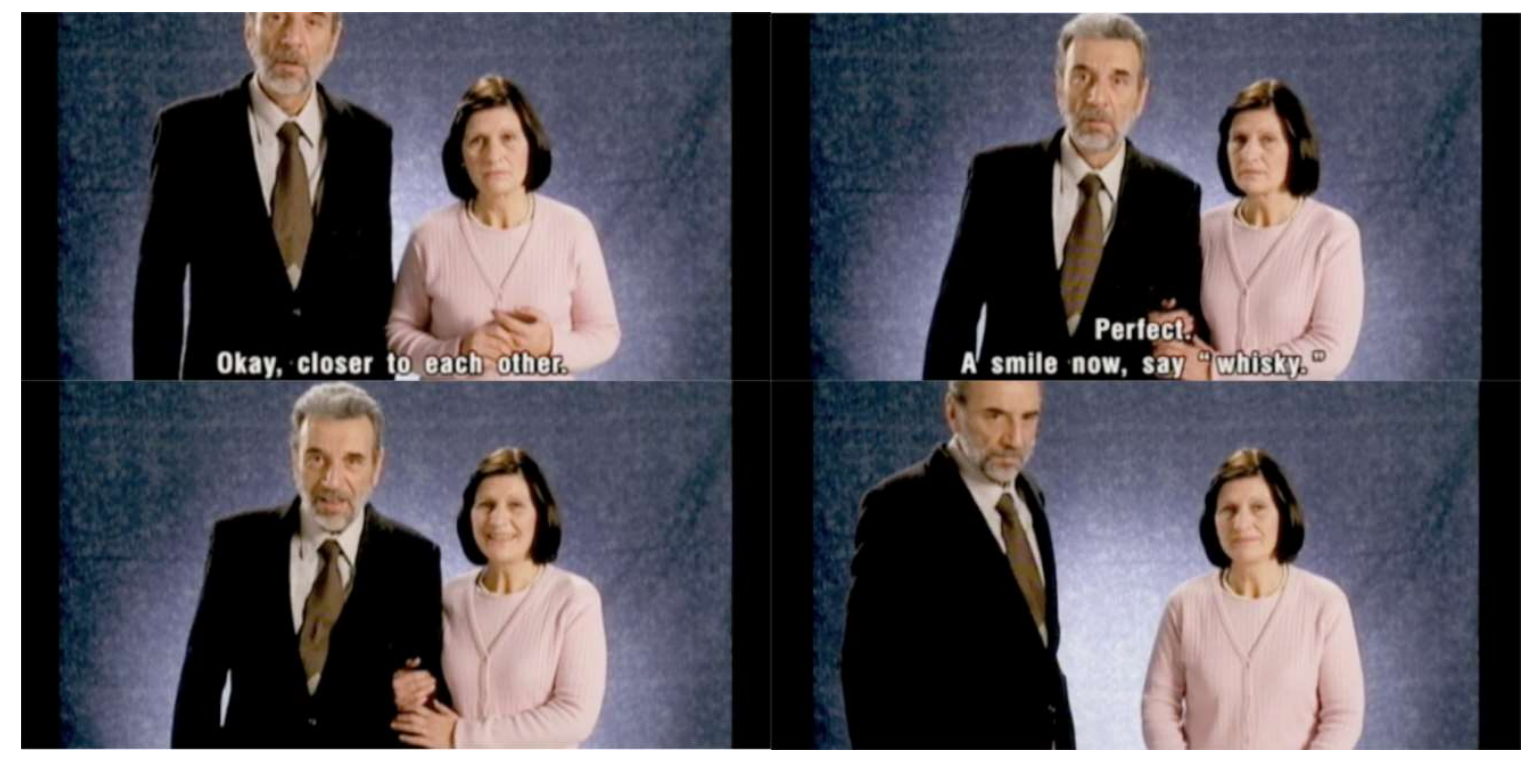

Image 1

Screenshots of Whisky (2004).

At the beginning of the scene, Jacobo and Marta are posing for the camera in medium shot. Jacobo, however, is too tall and does not fit in the 
frame. From off-screen, the photographer tells them to get closer together. He also tells Marta to hold Jacobo's arm and for him to lower himself so he will fit in the frame. Once the couple is in position, the photographer tells them to say whisky, the title of the movie. The result, which will be framed and placed in Jacobo's living room, is supposed to represent a moment after their wedding or the honeymoon. Immediately after the picture is taken, Jacobo pulls his arm away from Marta, goes back to his usual frown, and the top of his head no longer appears in the frame, while Marta holds her position and expression for a little longer. The picture that they are taking has the sole purpose of being used as proof of their marriage. It needed a camera, a photographer, and a frame to create a physical object to be left in Jacobo's living room to be seen by his brother. The picture is symbolic of a value of truth as it becomes evidence of the veracity of the tale they are presenting. Even more so, it is photographic evidence of an event that never happened. In this sense, this scene calls attention to the truth value of everything presented on the screen, be it either diegetic or extradiegetic. This meta-cinematic element ties back to one of the main themes of the movie, i.e., the fictionalization of identity, its performance, and, most importantly, the impossibility of truly knowing someone else. The gap that separates people becomes, like the framing of this scene and many others throughout the movie, absolutely uncrossable. The erasure of Uruguayan elements, in the mise-en-scène, together with Álvarez's choice of framing, highlight the fragmentation of identity, the isolation of existence, and incompleteness of human perception.

The very presence of the photographer who gave instructions to the characters in the abovementioned scene is indicative of the power of the camera and whoever controls it. The final word that can be heard from the offscreen photographer is whisky, which is one of the words commonly used to simulate smiles in posed pictures. It is also the title of the movie, suggesting that there is a strong similarity between the camera and the beholder-maybe that the camera is simply a beholder's perspective frozen in time-without, however, ignoring the complexities and nuances of the framing, the subjective 
choices of the photographer, and the performances of those depicted. If the picture is a single-point-in-time memento of a consideration of performance, perspective, and the commingling of the agency and the perception of narratives of individuality, the movie-titled Whisky and the caricatural characters apparently posing for a picture (Image 2)-constitutes a longer consideration of the same.

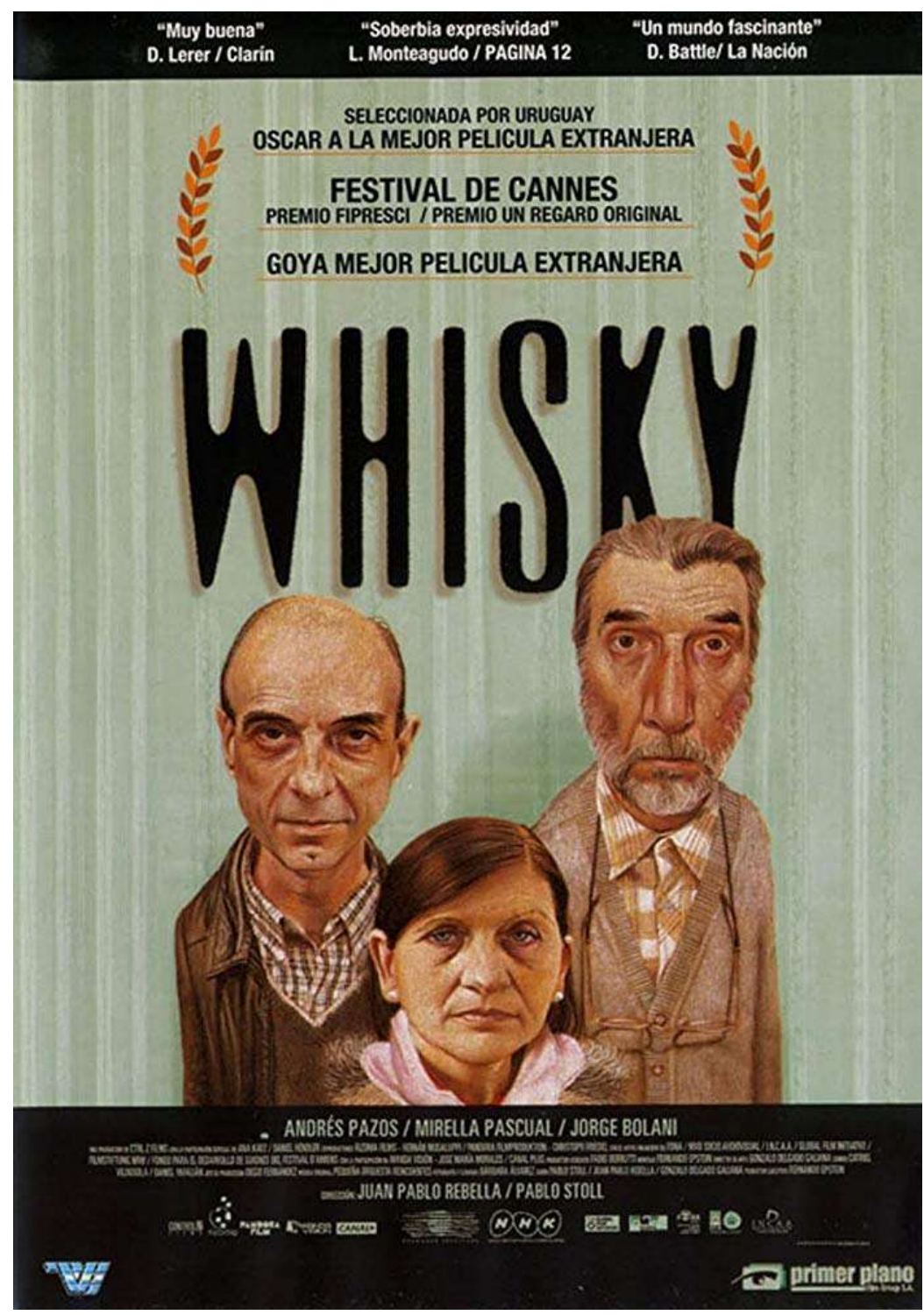

Image 2

Film poster of Whisky (2004). 
In a nutshell, Whisky presents us with the day-to-day reality of Jacobo and Marta followed by the fiction they fabricate to deceive Herman. From the beginning, the spectator is aware of the intentionality of Jacobo's fictionalization of his own life. The photographer's line say whisky encapsulates both a level of authorship in such fictions as well as its selection. At first Jacobo, and then all the other characters, are suggested to have responsibility for the fiction of identity presented without any dismissal of whomever is perceiving such performance. Whisky, as said by the photographer of this diegetic falsification, ties back to the title of the movie and to a extradiegetic meaning that the whole movie is a work of fiction, inviting viewers to consider their own personal fictions, the ones they perceive of the people with whom they interact, as well as the ones they advance about themselves, and, more importantly, the barriers it creates and its limits.

The camera work of Bárbara Álvarez highlights the limitations of both the performance and the reception of individual fictions, encapsulated in the use of the word whisky in the title as well as diegetically in the movie. At the beginning of the movie, before there is an explicit need to fictionalize Jacobo's life to his brother, characters are often not completely in frame or they are interacting with off-screen objects, such as when Jacobo asks the restaurant owner to turn the lights on, or when Marta brings Jacobo a hot beverage while he is trying to fix the curtains in his office, or when Marta checks the bags of the other women who work at the factory before they leave (Images 3, 4 and 5).

Recurring frames that leave important images partially off-screen, such as in the aforementioned examples, emphasizes the incompleteness of our perception as well as the characters' fragmented identities. This is confirmed by Whittaker's discussion of Whisky (2004) and Blue Eyelids (2007) when he says 
that "[t]he dialogue, or lack thereof, also frequently serves to emphasize offscreen space in the film" ${ }^{34}$.

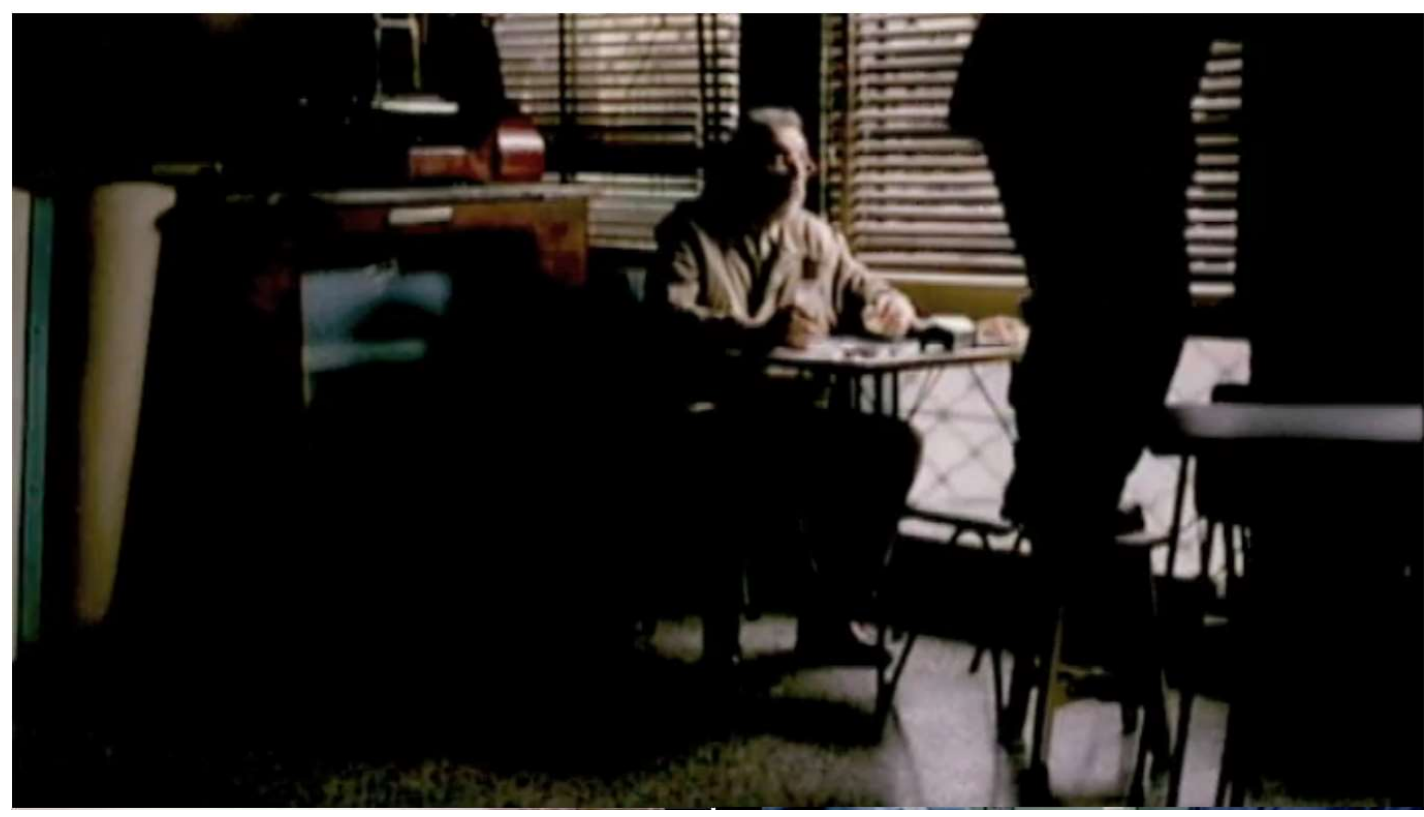

Image 3

Screenshots of Whisky (2004).

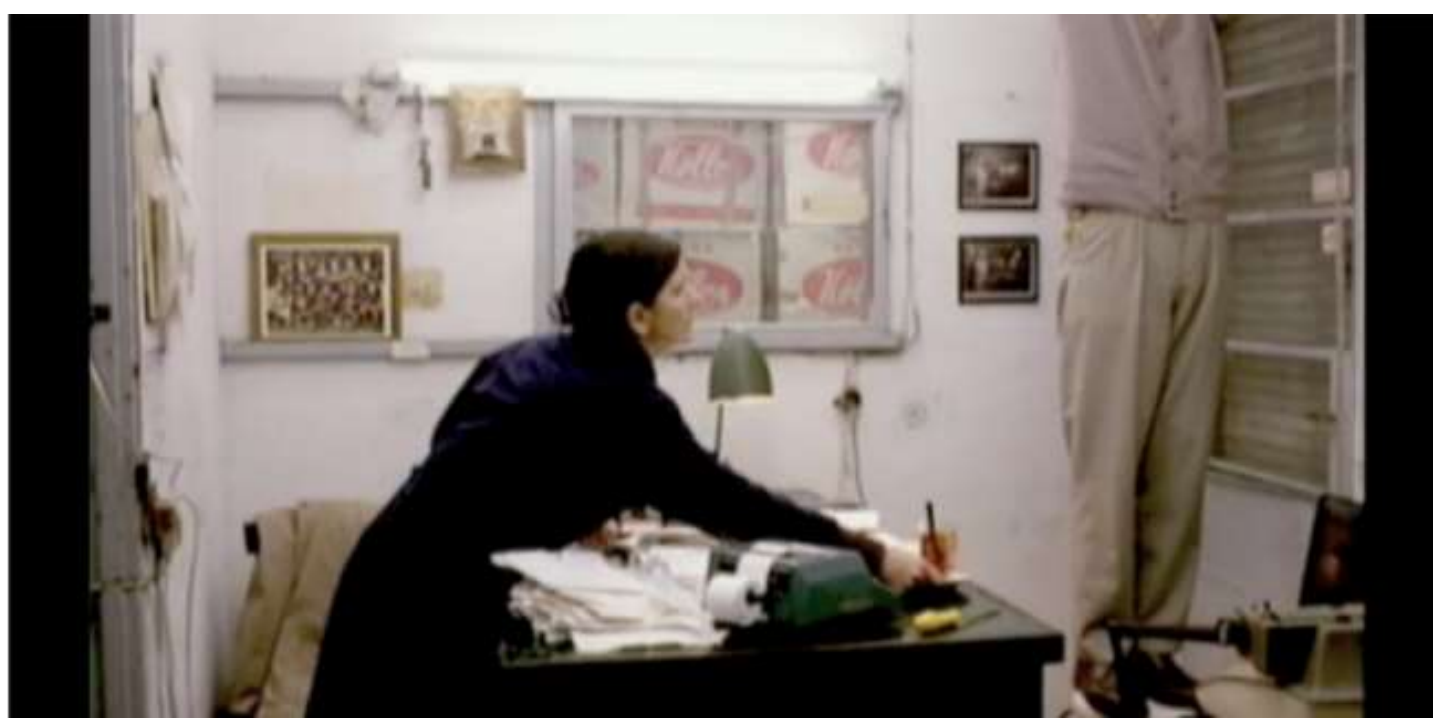

Image 4

Screenshots of Whisky (2004).

${ }^{34}$ Tom Whittaker, Of Machines and Routines: Mundane Rhythms and Sounds in Whisky (2004) and Blue Eyelids (2007), 2015, p. 38. 


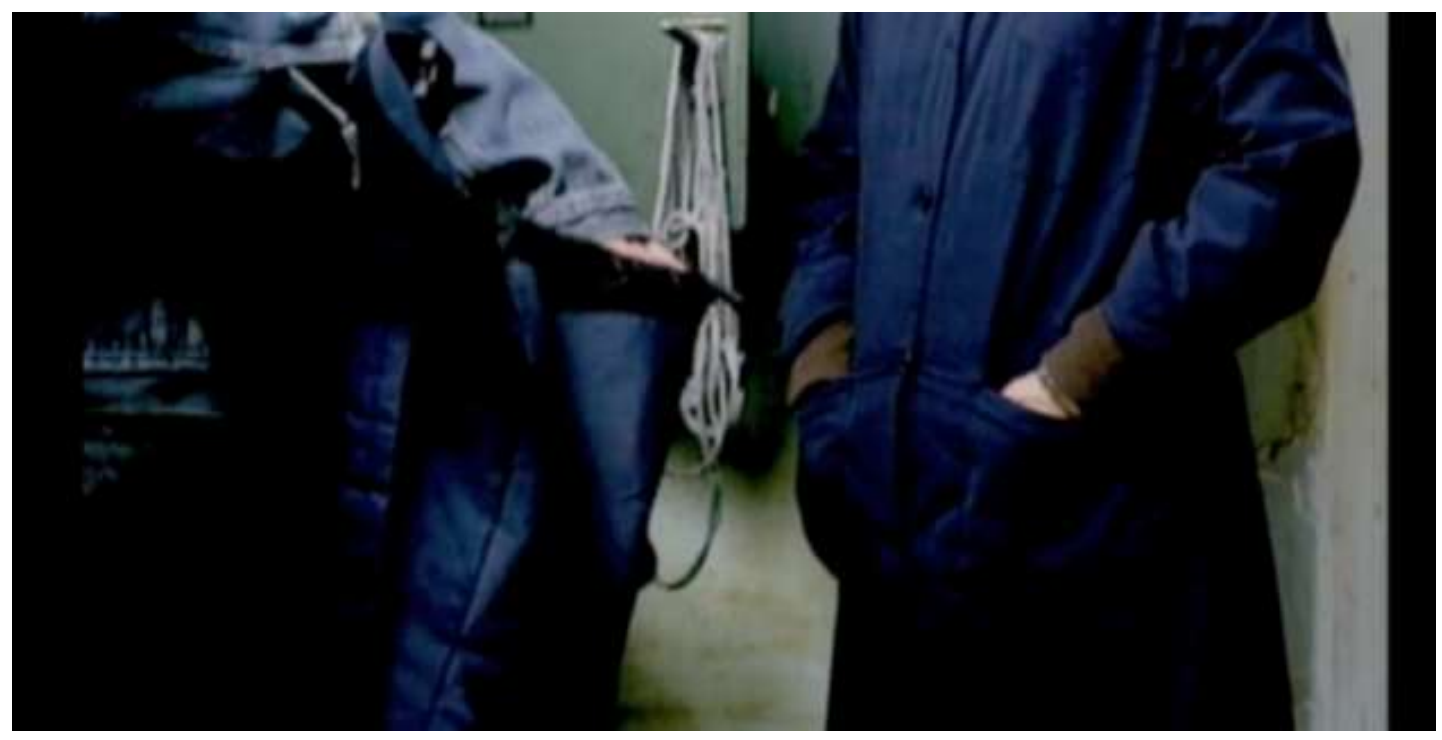

Image 5

Screenshots of Whisky (2004).

Furthermore, it highlights the gaps between the social performance of individuals and their perception. The same scholar discussed the importance of sound in Whisky. He points out that "[a] palpable sense of loneliness pervades both films, and much of their delicate sadness and dark humor reside in the characters' inability to communicate their feelings to one another" ${ }^{35}$. This is Whisky's strongest theme: the failure of communion, i.e., the impossibility of true communication, hence the isolation of existence.

Moreover, the scene that immediately precedes the one of picture of Marta and Jacobo there is more evidence of how the framing suggests the incompleteness of fictions. It is another static shot of the facade of Jacobo's sock factory. As Jacobo and Marta leave the factory at night, they exit the frame to the left. Jacobo parks his car nearby as shown at the beginning of the movie. It is an old car whose engine usually fails to start. After a few failed attempts at starting it, the factory's facade (0:29:19) appears in wide shot. From the left of the frame, Jacobo's car slowly makes its way to the center. Gradually it becomes clear that Marta is pushing the car while Jacobo drives and tries to

${ }^{35}$ Ibidem, p. 26. 
start it. As the engine starts, Marta stops pushing the car and soon enough she is left alone in the frame while the sound of the car's engine can still be heard moving to the right (Image 5).
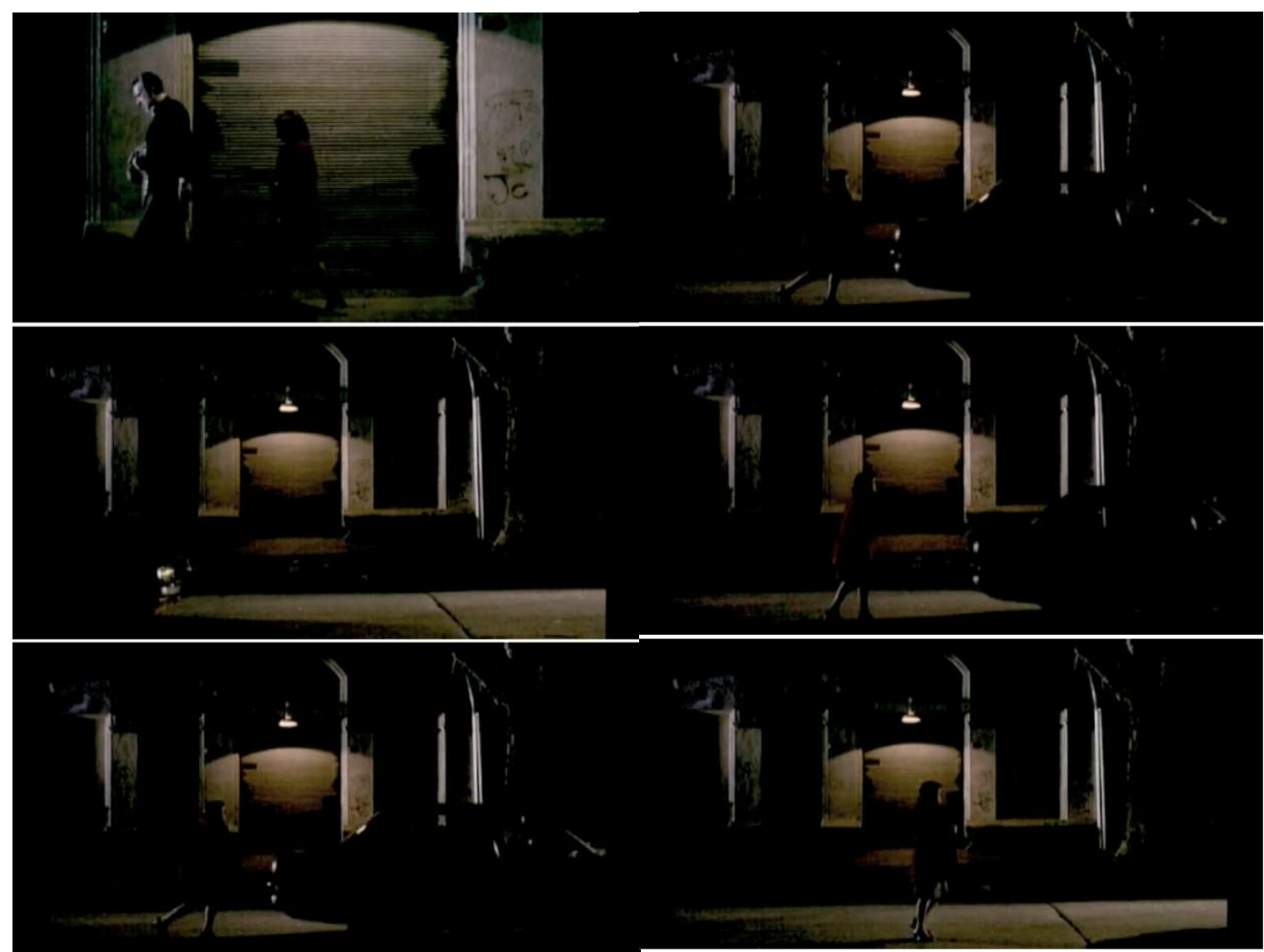

Image 5

Screenshots of Whisky (2004).

This scene serves to set the anti-climactic tone of the film's ending. It suggests that Marta will be left behind at Jacobo's first opportunity. In the end, however, after she receives the gift, it is Marta who leaves Jacobo to his own devices. His treatment of her during the whole film suggests that the social bond between them is broken. In this case, with a pinch of humor, it shows how the division of tasks between them mimics the neo-liberal logic of exploitation that alienates and reinforces the isolation of existence. The static camera suggests a less subjective perspective in this context once it is clearly 
not approaching any of the characters' point of view. At the same time, however, due to its function within this movie, it highlights its own limits. In this scene, the action starts off-screen on the left, moves on-screen in the center, and continues off-screen to the right. The editing and the sound allow for a sense of continuity that contrasts with the visual elements. Together with the scene in which they pose for the picture and the title of the movie, the scene in which Marta pushes the car stresses the limits of perception and subjective understandings.

In addition, this scene is representative of Marta and Jacobo's relationship. Jacobo owns the means of production and transportation. The movie begins with him driving his car to his factory. At other moments, Marta can be seen using public transportation. Except at the end of the movie, Marta is always already waiting at the factory's door for Jacobo's arrival, possibly due to his stop for breakfast (e.g. top image in Image 3). Her time and her work are subordinated to his to such a point that he cannot perceive her existence as something different than the sock-making machine in the factory or his car engine. His dependence on Marta's initiative and skill both in a personal as well as a business context is emphasized throughout the movie and seems to be acknowledged by Jacobo only after he wins in the casino with the money that his brother gave him. He does so through money only and discreetly, since Marta does not know she is receiving a huge amount of money when she accepts his gift-wrapped package.

If, however, the scene discussed above is representative of the social relations between Jacobo and Marta, it is also, due to the camera work and the themes of isolation present in the movie, an interpretation of a specific kind of alienation. In a movie in which so much is emphatically left unsaid and unshown, the relationship between the brothers and Marta demands a consideration regarding the distance between them. In the origin of Jacobo's request, there is a need to appear to his brother as something other than a loner: someone who is married, suggesting that there is a measure of success or 
happiness in companionship. This goes beyond money as a single measure of success. Jacobo's fictional performance to his brother suggests a hidden assumption about his own judgment of his brother and it is the camera work that invites the viewers to consider what lays beyond the screen. Their alienation from one another may go beyond a matter of social class and reach a quixotic understanding of reality and of the other as well.

In conclusion, Bárbara Álvarez's cinematography highlights the limits of understanding even among individuals who have known each other for a long time. In this analysis, two different scenarios concerning the relationship between the characters are presented. One in which they have been living apart from each other for a while, as it is the case of the Köller brothers, and another in which they have been working together so closely that they challenge the notion of individuality to reach an almost symbiotic condition, as is the case of Marta and Jacobo. Whisky's photography reasserts the incompleteness of the very possibility of knowledge, the existential isolation of people, the fragmented identities, and the uncrossable gaps between one's social performance and its perception. The playfulness of Bárbara Álvarez's framing, her choices of what is present in the mise-en-scène and what is absent, as well as the abovementioned meta-cinematic allusions are partially due to financial pressures during the shooting and partially due to a selective erasure of Uruguayan themes and images in order to appeal to international audiences. In view of the above, Whisky's formal composition both frames and conveys meaning. Its formal composition is a critical component of its meaning for local as well as global readings. The title emphasizes that even the smiles in the pictures are fictional, as they are just the still image of a mouth enunciating the word whisky.

\section{References}

ALFORD, Matthew. Reel Power: Hollywood Cinema and American Supremacy. 
London: Pluto Press, 2010.

ALFORD, Matthew. The Political Impact of the Department of Defense on Hollywood Cinema. Quarterly Review of Film \& Video, vol. 33, no. 4, 2016.

ALFORD, Matthew. Washington DC's Role behind the Scenes in Hollywood Goes Deeper than You Think. The Conversation, Disponível em: $<$ http://theconversation.com/washington-dcs-role-behind-the-scenes-inhollywood-goes-deeper-than-you-think-80587>. Acesso em: 21 Nov. 2018.

BROWN, William. Non-Cinema Global Digital Film-Making and the Multitude. New York: Bloomsbury Academic \& Professional, 2018. Open WorldCat, http://public.eblib.com/choice/PublicFullRecord.aspx?p=5402066.

DOBRICH, Miguel Ángel. Duelo con el montajista y productor cinematográfico Fernando Epstein. 118, Disponível em: <https://soundcloud.com/dobcast/118mvd-no-fernando-epstein>. Acessado em: 3 Dec. 2018.

FUICA, Beatriz Tadeo. Uruguayan Cinema, 1960-2010: Text, Materiality. Archive. Woodbridge: Boydell \& Brewer, 2017. ProQuest Ebook Central, http://ebookcentral.proquest.com/lib/ohiostateebooks/detail.action?docID=4939462.

HIGSON, Andrew. The Concept of National Cinema. In: WILLIAMS, Allan (Ed.). Film and Nationalism. Rutgers University Press, 2002, pp. 52-67.

HIGSON, Andrew. The Limiting Imagination of National Cinema. In: HJORT, Mette; MACKENZIE, Scott. (Ed.). Cinema and Nation. London, Psychology Press, 2000.

HJORT, Mette. Cinema of Small Nations. Edinburgh: Edinburgh University Press, 2007.

LONGXI, Zhang. The 'Tao' and the 'Logos': Notes on Derrida's Critique of Logocentrism. Critical Inquiry, vol. 11, no. 3, 1985, pp. 385-98. 
MARTIN-JONES, David; MONTAÑEZ, Soledad. Cinema in Progress: New

Uruguayan Cinema. Screen, vol. 50, no. 3, Oct. 2009, pp. 334-44.

academic.oup.com, doi:10.1093/screen/hjp015.

MARTIN-JONES, David; MONTAÑEZ, SoledadUruguay Disappears: Small Cinemas, Control Z Films, and the Aesthetics and Politics of Auto-Erasure.

Cinema Journal, vol. 53, no. 1, 2013, pp. 26-51.

WHYSKY. Juan Pablo Rebella and Pablo Stoll (Dir.). Uruguay: Fernando Epstein, MK2 Diffusion, 2004. 1 filme (99 min), son., color., 35mm.

WHITTAKER, Tom. Of Machines and Routines: Mundane Rhythms and Sounds in Whisky (2004) and Blue Eyelids (2007). Journal of Film \& Video, vol. 67, no. 2, Summer 2015, pp. 35-43.

\section{Referência para citação deste artigo}

GEMELLI, Cesar. Existential isolation in Whisky (2004), reading uruguayan cinema beyond the concept of small cinema. Revista PHILIA | Filosofia, Literatura \& Arte, Porto Alegre, volume 1, número 2, p. 146 - 166, outubro de 2019. 